\title{
The Role of Interstitial Cells of Cajal in Acute Cholecystitis in Guinea Pig Gallbladder
}

\author{
Zhen-peng Huang ${ }^{a, b}$ Hu Qiu ${ }^{a, b}$ Yan Yanga ${ }^{a, b}$ Li Zhang ${ }^{c}$ Bin Yang ${ }^{a, b}$ \\ Meng-juan Lin ${ }^{a, b}$ Bao-ping Yu ${ }^{a, b}$
}

aDepartment of Gastroenterology, Renmin Hospital of Wuhan University, Wuhan, 'ey Laboratory of Hubei Province for Digestive System Diseases, Wuhan, 'Department of Gastroenterology, The First Affiliated Hospital of Chongqing Medical University, Chongqing, China

\section{Key Words}

Interstitial Cajal cells $•$ Acute cholecystitis $\bullet$ Stem cell factor $\bullet$ C-kit

\begin{abstract}
Background/Aims: Acute cholecystitis is common in gallbladder motility disorder. Interstitial cells of Cajal (ICCS) in the gallbladder are involved in the regulation of gallbladder motility. The aim of this study was to explore the change of gallbladder ICCs in acute cholecystitis. Methods: Thirty adult guinea pigs were randomly divided into 3 groups: a sham-operated group (healthy controls) and 2 study groups. The animals in the study group were subjected to bile duct ligation and then to laparotomy and cholecystectomy at 24 and 48 hours after surgery. Immunohistochemistry, immunohistofluorescence, and laser confocal microscopy were performed to observe the shape, size, morphology, and density of gallbladder ICCs. Western blot and real-time PCR were performed to detect stem cell factor and c-kit protein and mRNA expression, respectively. Results: There were no differences in the shape, size, and morphology of the gallbladder ICCs in the control and the two acute cholecystitis groups. Density of gallbladder ICCs, SCF level, and c-kit protein and mRNA expression all decreased in the acute cholecystitis groups. Further, SCF level and c-kit protein and mRNA expression decreased with progress of acute cholecystitis (all $P<0.05$ ). Conclusion: Acute cholecystitis can decrease ICCs through repression of SCF and c-kit expression and that ICCs loss play a role in acute cholecystitis.

\section{Introduction}

Acute cholecystitis is a frequent reason for a visit to the emergency department. It is caused by many factors, such as gallstones, motility disorders, and direct chemical injury [1, 2]. Most cases of acute cholecystitis occur with gallbladder motility disorder [2, 3]. 


\section{Cellular Physiology Cell Physiol Biochem 2016;38:1775-1784

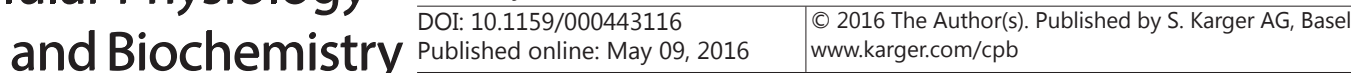 \\ Huang et al.: Gallbladder Interstitial Cells of Cajal Injured in Acute Cholecystitis}

Gallbladder motility is regulated by various mechanisms, and interstitial cells of Cajal (ICCs) in the gallbladder are involved in generating and spreading the spontaneous contractions of the gallbladder, promoting gastrointestinal electrical activity, and mediating and regulating neurotransmitters of the gastrointestinal tract [4-9]. Gallbladder ICCs have also been linked to various biliary system diseases, such as cholelithiasis, and malignant tumors of the biliary system $[10,11]$. However, it remains unclear whether decrease in the density of gallbladder ICCs would induce acute cholecystitis and whether abnormalities in gallbladder ICCs and the SCF/c-kit pathway can lead to acute cholecystitis. The present study was designed to explore the cellular and molecular mechanisms of gallbladder ICCs in acute cholecystitis in a guinea pig model. We used immunohistochemistry, immunohistofluorescence, and laser confocal microscopy to observe the shape, size, morphology, and density of gallbladder ICCs, and western blot and real-time PCR (RT-PCR) were used to detect stem cell factor (SCF) and c-kit protein and mRNA expression, respectively.

\section{Materials and Methods}

\section{Animals and Animal experiments}

Thirty adult guinea pigs (males and females; weight, 250 - $350 \mathrm{~g}$ ) were obtained from Wuhan Institute of Biological Products Company with Limited Liability. The guinea pigs were maintained in standard laboratory conditions $\left(22 \pm 2^{\circ} \mathrm{C}\right.$ with a $12 \mathrm{~h}$ light/dark cycle and a relative humidity of $\left.40-60 \%\right)$. The guinea pigs were given access to diet and water freely. All animal experiments were approved by the Institutional Animal Care and Use Committee of Wuhan University, and the protocol was designed to minimize pain and discomfort to the animals.

For experiments involving bile duct ligation (BDL), guinea pigs were randomly divided into 3 groups (10 animals per group). The sham-operated group constituted the healthy control group. The animals in the study groups were subjected to BDL. The animals in the BDL $24 \mathrm{~h}$ group and the BDL $48 \mathrm{~h}$ group were subjected to laparotomy and cholecystectomy at 24 and $48 \mathrm{~h}$ after surgery, respectively [12-15].

Hematoxylin-eosin staining was performed for 1 gallbladder specimen from each group for detecting the degree of acute cholecystitis using a light microscope (Olympus BX53, Tokyo, Japan).

\section{Immunohistochemistry}

Immunohistochemistry was performed on paraffin-embedded sections by using a microwave-based antigen retrieval technique. Gallbladder specimens fixed in 4\% polyformaldehyde solution and embedded in paraffin. The paraffin-embedded sections were cut to $5 \mu \mathrm{m}$ thickness and mounted on positively charged slides. First, the sections were identified by incubation with rat monoclonal antibody raised against CD117/c-kit (eBioscience, San Diego, USA) at room temperature for 24 hours, followed by incubation with appropriate secondary antibodies. Subsequently, the sections were stained with diaminobenzidine and counterstained with hematoxylin. The stained samples were observed under a light microscope (Olympus BX53, Tokyo, Japan). Images of CD117/c-kit-positive cells were taken for 5 randomly chosen fields $(\times 400$ magnification) per section by fluorescence microscope. The CD117/C-kit-positive cell density was assessed with the Image-Pro plus 6.0 software (Media Cyber-netics, Bethesda, MD, United States).

\section{Immunohistofluorescence with laser confocal microscopy observation}

Gallbladder specimen was fixed in $4 \%$ polyformaldehyde solution and stored at $4^{\circ} \mathrm{C}$ for $30 \mathrm{~min}$. Subsequently, the gallbladder specimen was washed with phosphate-buffered saline (PBS) for 10 min 3 times. After fixing, the gallbladder specimen was cut. Fixed samples were dipped in PBS with $0.3 \%$ Triton $\mathrm{X}-100$ followed by blocking with normal goat serum for $30 \mathrm{~min}$ at room temperature. Next, the samples were incubated with primary rat monoclonal anti-c-kit antibody (eBioscience, San Diego, USA) at $4{ }^{\circ} \mathrm{C}$ overnight. Then, gallbladder tissues were washed for $10 \mathrm{~min} 3$ times with tris-buffered saline and tween-20 solution (TBST) and were incubated with a CY3-conjugated rabbit anti-rat secondary antibody in PBS for 1 $\mathrm{h}$ at room temperature. After removing the unbound secondary antibody by washing with TBST for 5 min 3 times, they were mounted on a slide with a coverslip sealed with glycerol. Images were captured by laser confocal microscope (Olympus FV1000, Tokyo, Japan). 


\section{Cellular Physiology Cell Physiol Biochem 2016;38:1775-1784 \begin{tabular}{l|l} 
and Biochemistry & DOI: 10.1159/000443116 \\
Published online: May 09, 2016 & $\begin{array}{l}\text { (c) 2016 The Author(s). Published by S. Karger AG, Basel } \\
\text { www.karger.com/cpb }\end{array}$
\end{tabular} \\ Huang et al.: Gallbladder Interstitial Cells of Cajal Injured in Acute Cholecystitis}

Protein extraction and Western blot analysis

Gallbladder muscular layer tissues from 1 guinea pig (weight $150 \mathrm{mg}$ ) were used for protein extraction with RIPA lysis buffer. Electrophoresis in 10\% SDS polyacrylamide gels was performed and the bands were transferred to a nitrocellulose membrane (Pierce Biotechnology, Inc., Rockford, USA). Then, the membrane was incubated with 5\% skim milk at room temperature to block nonspecific binding sites for $2 \mathrm{~h}$. The samples were incubated with primary antibody against c-kit (eBioscience, San Diego, USA) or SCF (Abcam, Cambridge, UK) overnight at $4^{\circ} \mathrm{C}$. After washing with TBST for $10 \mathrm{~min}$ times, the secondary antibody of matching conjugated horse radish peroxidase was applied for $1 \mathrm{~h}$ at room temperature. Specific protein bands were visualized in X-ray film (Kadok China Investment Co. Ltd., Xiamen, China) by using the chemiluminescence detection kit (ECL; Amersham, Pittsburgh, USA). Optical density of the bands was analyzed with Alpha Innotech (Alpha Innotech Co., California, USA).

\section{RNA Extraction}

For RNA extraction, 150 mg gallbladder muscular layer from 1 guinea pig was used. Total RNA was extracted with the TRIzol reagent (Invitrogen) following the manufacturer's instructions.

\section{RT-PCR Analysis}

cDNA was reverse-transcribed from $4.885 \mu \mathrm{g}$ of total RNA and amplified by 40 cycles of denaturation $\left(2 \mathrm{~min}\right.$ at $50^{\circ} \mathrm{C}, 10 \mathrm{~min}$ at $\left.95^{\circ} \mathrm{C}\right)$, annealing $\left(30 \mathrm{sec}\right.$ at $\left.95^{\circ} \mathrm{C}\right)$ and synthesis $\left(30 \mathrm{sec}\right.$ at $\left.60^{\circ} \mathrm{C}\right)$. The primers for GAPDH were 5'-ATC ACT GCC ACC CAG AAG ACT-3' (forward) and 5'-CAG ATC CAC AAC CGA CAC ATTA3'(reverse). The generated amplicon was $195 \mathrm{bp}$. The primers for SCF were 5'-GAA AGA TTC CAG AGT CAG TGTCA-3' (forward) and 5'-AAG CAA AGC CAA TCA CAA GAG-3' (reverse), and generated an amplified product of $179 \mathrm{bp}$. The primers for c-kit were 5'-TAT CCT CCT TAC TCA TGG TCGAA-3' (forward) and 5'CGG GCA TTT CCT TTA ACC ACATA-3' (reverse), and generated amplicons of $99 \mathrm{bp}$. Subsequently, the PCR product was separated by electrophoresis with size markers on a $1.5 \%$ agarose gel stained with ethidium bromide. The GAPDH gene was used as an internal control. The mRNA values were expressed as relative units, and the ratio of density between the SCF/c-kit amplification product and the GAPDH amplification product was calcuated.

\section{Statistical Analysis}

All statistical analyses were performed using SPSS for Windows version 17.0 (SPSS, Chicago, USA). Continuous variables were presented as mean \pm standard deviation (SD). Continuous variables were compared using the $t$ test. Categorical variables were compared using ANOVA. A two-sided $P$ value $<0.05$ was regarded as statistically significant.

\section{Results}

\section{Evaluation of animal model}

No guinea pigs from the sham-operated group and the BDL $24 \mathrm{~h}$ group died, whereas 3 guinea pigs died in the BDL 48 h group (mortality rate, 30\%) due to cholecystic duct obstruction and gallbladder rupture.

In histopathological analysis, gallbladder tissue from the sham-operated group was found to be intact and without obvious inflammatory cell infiltration. In contrast, gallbladder tissue from the BDL 24 hour group showed edema, blood-expanded hyperemia, and inflammatory cell infiltration. Gallbladder tissue from the BDL $48 \mathrm{~h}$ group, showed edema and hyperplasia of fibroblasts, blood-expanded hyperemia and hemorrhage, and a large number of inflammatory cell infiltration (mainly neutrophils) in the mucosa and muscularis (Fig.1).

These findings indicate that BDL may induce acute cholecystitis in guinea pigs.

\section{Immunohistochemical analysis}

Gallbladder ICCs were predominantly fusiform in shape with several slender lateral branches in all groups. ICCs were predominantly located in the muscular layer, mostly within the muscularis propria, and were primarily located parallel to smooth muscle cells. The ICCs 


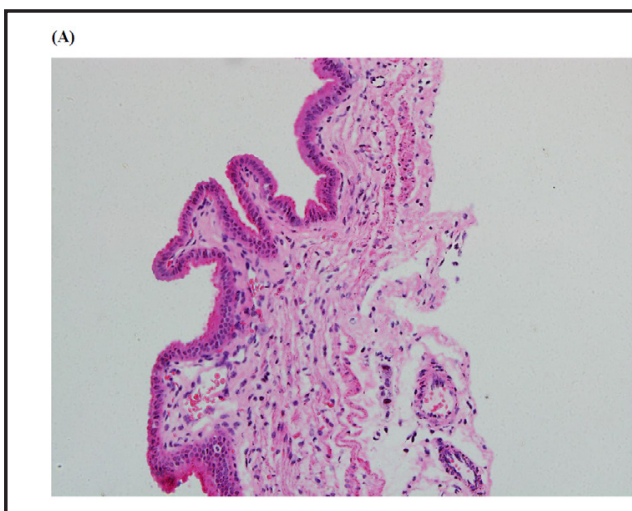

(B)

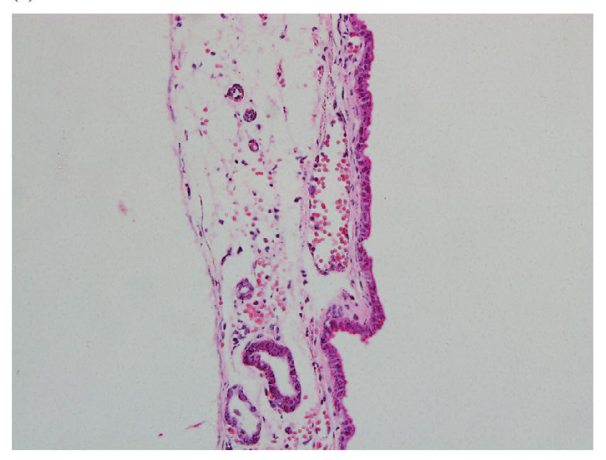

(C)

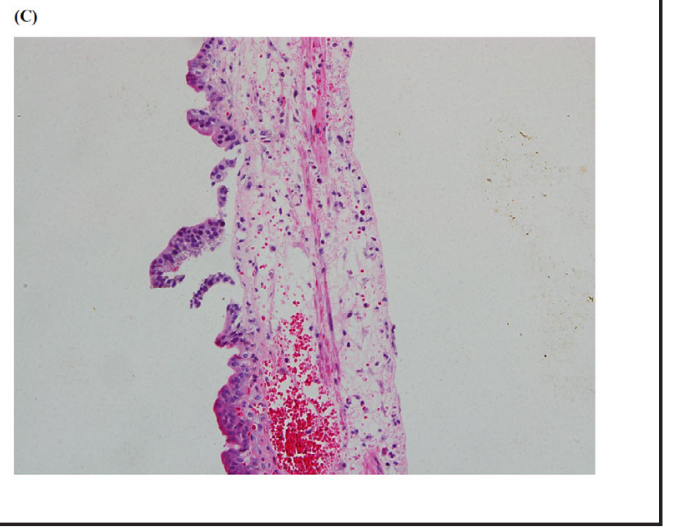

Fig. 1. Histopathological analysis on animal model (200X). (A) Gallbladder tissue from the sham-operated group was found to be intact and without obvious inflammatory cell infiltration. (B) Gallbladder tissue from the BDL 24 hour group showed edema, blood-expanded hyperemia, and inflammatory cell infiltration. (C) Gallbladder tissue from the BDL $48 \mathrm{~h}$ group, showed edema and hyperplasia of fibroblasts, blood-expanded hyperemia and hemorrhage, and a large number of inflammatory cell infiltration (mainly neutrophils) in the mucosa and muscularis.

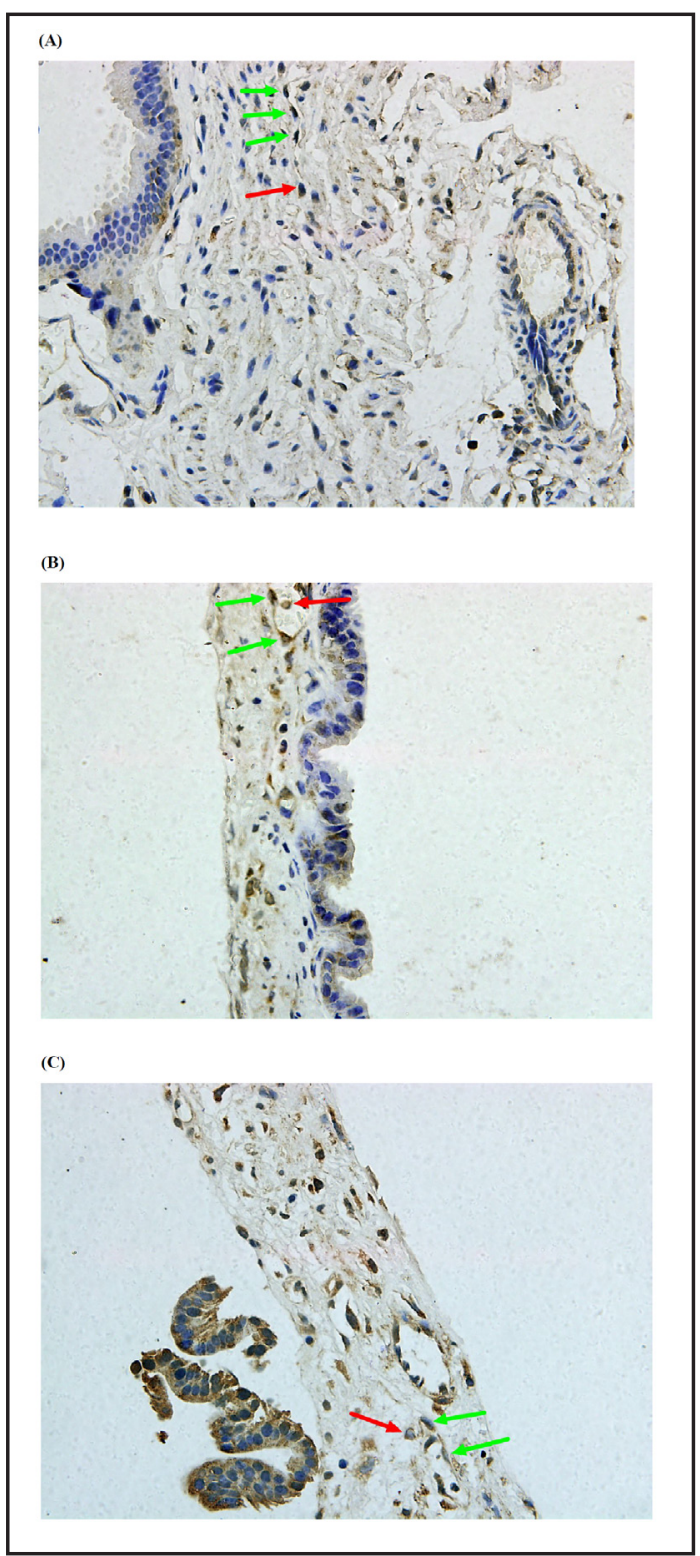

Fig. 2. Immunohistochemical observation (400X). Gallbladder tissues were from the sham-operated group (A), the BDL 24 hour group (B) and the BDL 48 $\mathrm{h}$ group (C). Gallbladder ICCs (green arrows) were predominantly fusiform in shape with several slender lateral branches in all groups. ICCs were predominantly located in the muscular layer, mostly within the muscularis propria, and were primarily located parallel to smooth muscle cells. The ICCs typically appeared singly or in small clusters of two to three cells. Besides, mast cells (red arrows) were also immunolabeled positively for Kit, and were observed in the mucosa of the gallbladders.

typically appeared singly or in small clusters of two to three cells. Besides, mast cells were also immunolabeled positively for Kit, and were observed in the mucosa of the gallbladders (Fig. 2). 


\section{Cellular Physiology Cell Physiol Biochem 2016;38:1775-1784 \begin{tabular}{c|c|c|c|} 
DOI: 10.1159/000443116 & $\begin{array}{l}\text { O 2016 The Author(s). Published by S. Karger AG, Basel } \\
\text { www.karger.com/cpb }\end{array}$
\end{tabular} \\ Huang et al.: Gallbladder Interstitial Cells of Cajal Injured in Acute Cholecystitis}

Fig. 3. Density of ICCs in the sham-operated group and the BDL groups. With immunohistochemical analysis, images of CD117/c-kit-positive cells were taken for 5 randomly chosen fields $(\times 400$ magnification) per section by fluorescence microscope. Density of ICCs was decreased in the BDL groups, density of ICCs in the BDL $48 \mathrm{~h}$ group was lower than the BDL 24h group $(42.0000 \pm 2.00000$ vs. $26.3333 \pm 1.52753$ vs. $20.0000 \pm 1.00000$, $F=157.409, P<0.05)$.
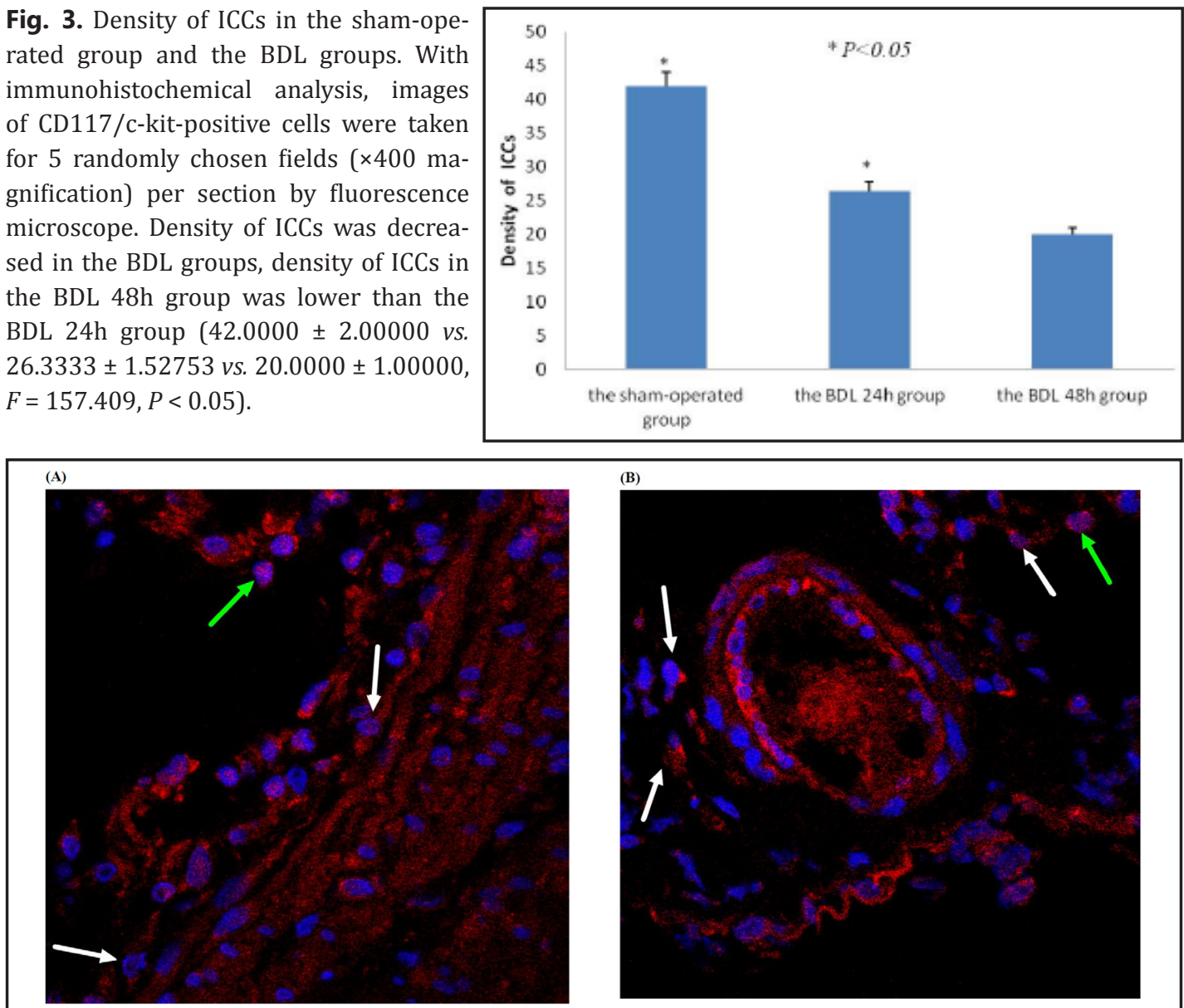

Fig. 4. Immunohistofluorescence with laser confocal microscopy observation (630X). Gallbladder tissues came from the sham-operated group (A), the BDL 24 hour group (B) and the BDL $48 \mathrm{~h}$ group (C). Gallbladder ICCs (white arrows) were predominantly fusiform in shape with several slender lateral branches in all groups. ICCs were predominantly located in the muscular layer, mostly within the muscularis propria, and were primarily located parallel to smooth muscle cells. The ICCs typically appeared singly or in small clusters of two to three cells. Mast cells (green arrows) were observed in the mucosa of the gallbladders. However, there were no differences in the shape, size, and morphology of the ICCs in all groups.

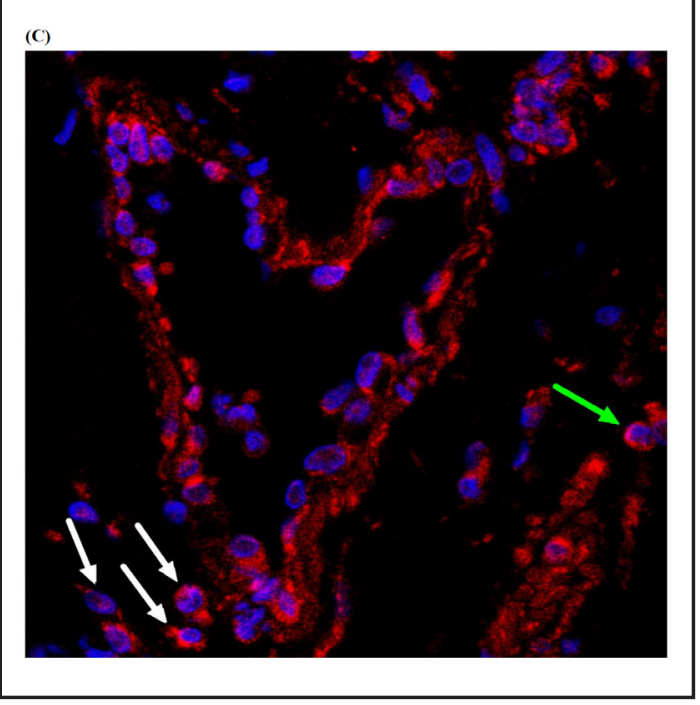

The number of ICCs in the sham-operated group was significantly higher than that in the two BDL groups. However, there were no differences in the shape, size, and morphology of the ICCs in all groups. ICC density in the BDL groups was significantly lower than that in the sham-operated group. Furthermore, the density of ICCs in the BDL 48 h group was lower than that in the BDL 24 h group $(42.0000 \pm 2.00000$ vs. $26.3333 \pm 1.52753$ vs. $20.0000 \pm$ $1.00000, F=157.409, P<0.05)$. In acute cholecystitis guinea pigs, gallbladder ICCs density was decreased (Fig. 3). 


\section{Cellular Physiology Cell Physiol Biochem 2016;38:1775-1784 \begin{tabular}{c|c|c|} 
DOI: 10.1159/000443116 & $\begin{array}{l}\text { O 2016 The Author(s). Published by S. Karger AG, Basel } \\
\text { www.karger.com/cpb }\end{array}$
\end{tabular}

Fig. 5. SCF and c-kit protein expression in different groups. SCF and c-kit protein expression in BDL groups were decreased. SCF (A) and c-kit (B) protein expression levels were evaluated by western bolt analysis. Lane 1 was represented the sham-operated group, lane 2 came from the BDL $24 \mathrm{~h}$ group animals, lane 3 was from the BDL $48 \mathrm{~h}$ group guinea pigs. $\beta$-actin mean loading control. (C) The optical mean density of SCF and c-kit protein in all groups, each vertical line stood by the mean \pm standard deviation. The ratio
(A)

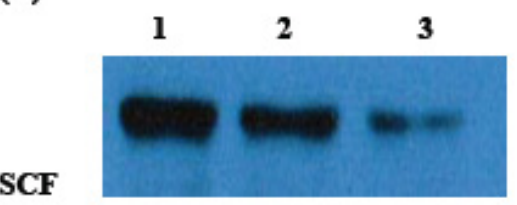

(B)

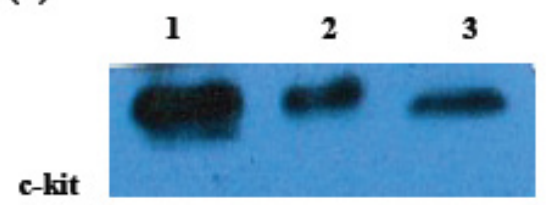

$\beta$-actin

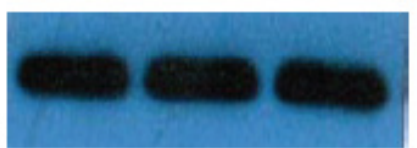

B-actin

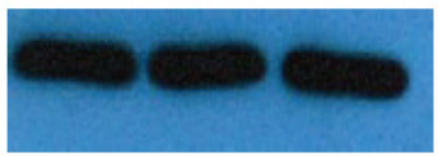

(C)

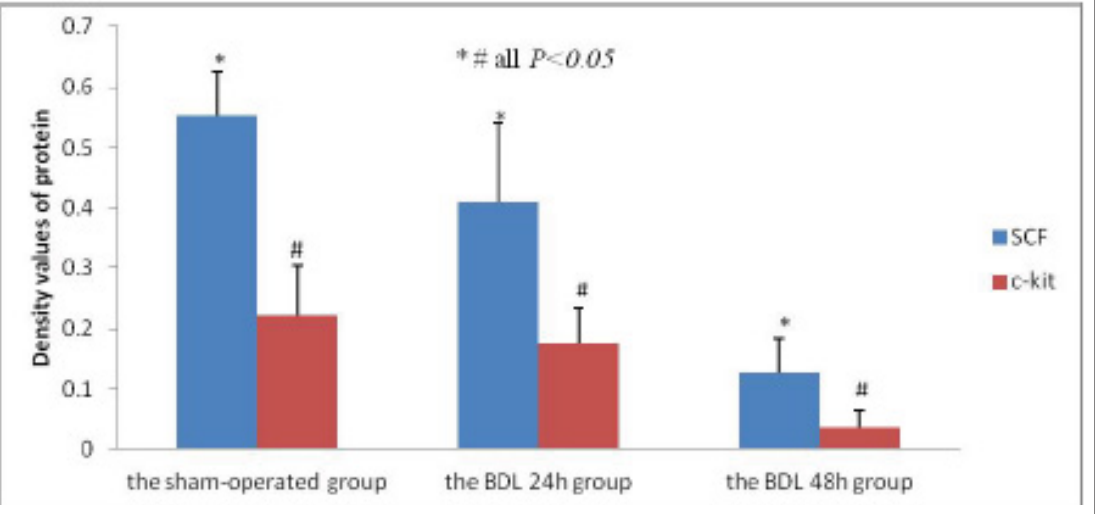

of SCF and $\beta$-actin in the sham-operated, BDL $24 \mathrm{~h}$, and BDL $48 \mathrm{~h}$ groups was $0.5533 \pm 0.07234,0.4100 \pm$ 0.13000 , and $0.1267 \pm 0.05859(F=16.596, P<0.05)$, respectively. The ratio of c-kit and $\beta$-actin was 0.2233 $\pm 0.08083,0.1767 \pm 0.05774,0.0367 \pm 0.02887$ ( $F$-values, respectively, were 16.596 and 7.938 , all $P<0.05$ ).

\section{Immunohistofluorescence analysis}

In fluorescence and laser confocal microscopic examination, gallbladder ICCs mainly appeared in the muscularis and were in the astrocyte or fusiformis shapes. ICCs that stained positive for c-kit had large, orbicular, or ovate nuclei; reduced cytoplasm; and scattered chromatin; each ICC also had 2-5 long synapses. ICCs were distributed throughout the wall of the gallbladder and were connected with each other to form a net-like structure.

Immunohistofluorescence analysis using laser confocal microscopy supported the findings of immunohistochemistry (Fig. 4).

SCF level and c-kit protein expression in the gallbladder of guinea pigs with acute cholecystitis

In western blot analysis, the protein levels of both c-kit and SCF were significantly lower in the BDL groups than in the sham-operated group. SCF and c-kit protein levels were lower in the BDL $48 \mathrm{~h}$ group than in the BDL $24 \mathrm{~h}$ group. The ratio of SCF and $\beta$-actin in the shamoperated, BDL $24 \mathrm{~h}$, and BDL $48 \mathrm{~h}$ groups was $0.5533 \pm 0.07234,0.4100 \pm 0.13000$, and $0.1267 \pm 0.05859$. The ratio of c-kit and $\beta$-actin was $0.2233 \pm 0.08083,0.1767 \pm 0.05774$, $0.0367 \pm 0.02887$ ( $F$-values, respectively, were 16.596 and 7.938 , all $P<0.05$ ).

SCF and c-kit protein expression was decreased in the two BDL groups, and gallbladder ICCs were loss in acute cholecystitis (Fig. 5).

mRNA expression of SCF and c-kit in the gallbladder of guinea pigs with acute cholecystitis

RT-PCR analysis revealed that the level of SCF and c-kit mRNA decreased in the BDL groups. SCF and c-kit mRNA level was much lower in the BDL $48 \mathrm{~h}$ group than in the BDL 


\section{Cellular Physiology Cell Physiol Biochem 2016;38:1775-1784 \begin{tabular}{c|c|c|} 
DOI: 10.1159/000443116 & $\begin{array}{l}\text { O 2016 The Author(s). Published by S. Karger AG, Basel } \\
\text { www.karger.com/cpb }\end{array}$
\end{tabular} \\ Huang et al.: Gallbladder Interstitial Cells of Cajal Injured in Acute Cholecystitis}

Fig. 6. mRNA expression of SCF and c-kit in different groups. The expression level of SCF and c-kit mRNA in the BDL groups were decreased. GAPDH (A), SCF (B) and c-kit (C) mRNA expression levels were detected by RT-PCR. Lane 1 was marker, lane 2 came from the sham-operated group guinea pigs, lane 3 was from the BDL 24h group animals, lane 4 was represented from the BDL $48 \mathrm{~h}$ group guinea pigs. (D) The mean optical density of SCF and c-kit mRNA/GAPDH in all groups, each vertical line stood by the mean \pm standard deviation. The sham-operated group, the BDL $24 \mathrm{~h}$ and BDL $48 \mathrm{~h}$ groups, the SCF and c-kit mRNA levels were $1.0000 \pm 0.00000$ vs. $0.4400 \pm$ 0.09539 vs. $0.2000 \pm 0.08544$ and $1.0000 \pm 0.0000$ vs. 0.5967 \pm 0.05132 vs. $0.2833 \pm 0.08622$, in respectively $(F$-values respectively were 92.488 and 115.401, all $P<0.05$ ).
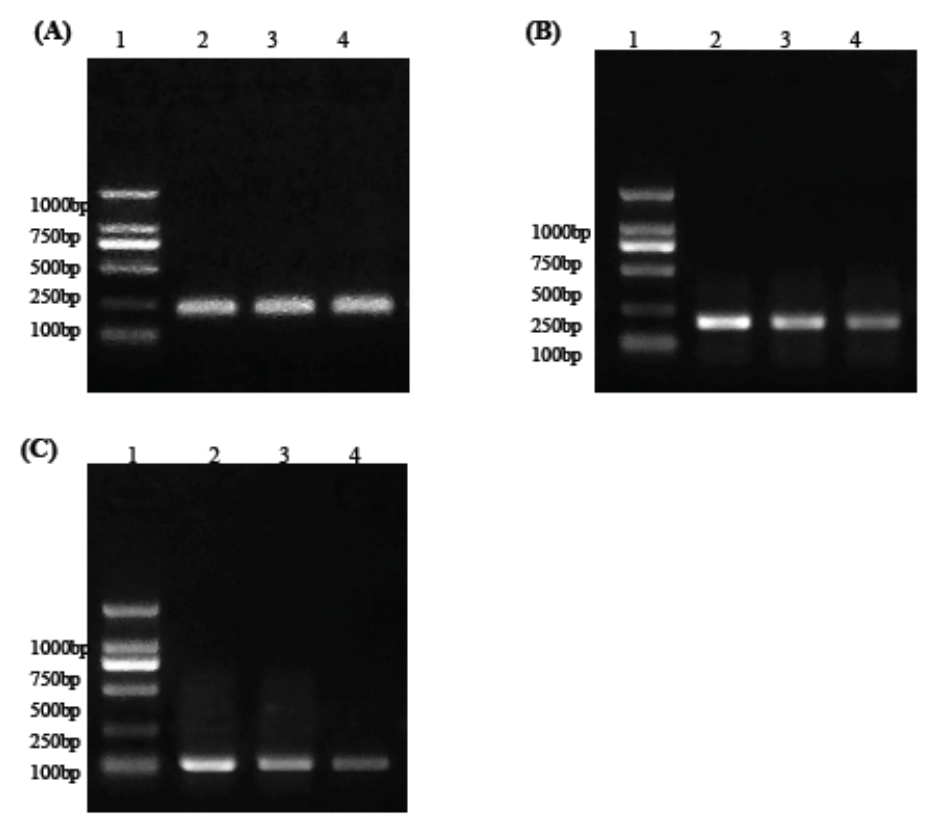

(D)

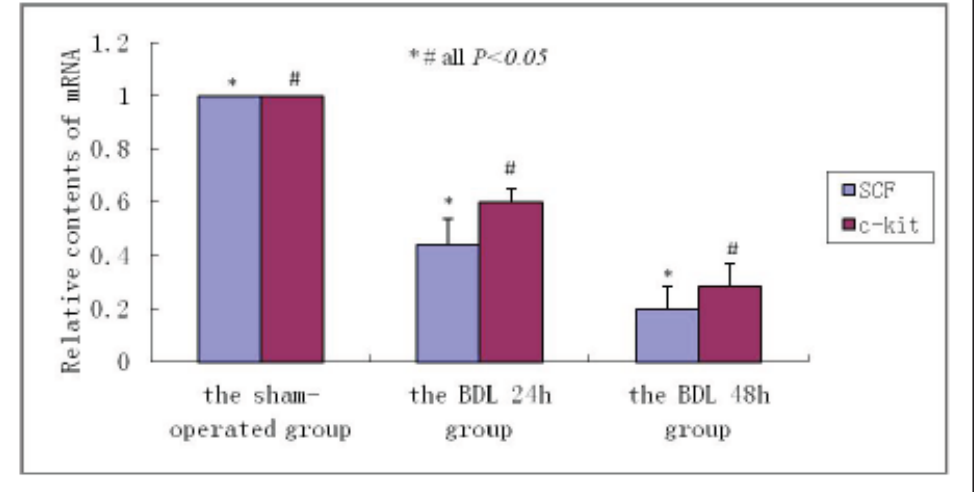

$24 \mathrm{~h}$ group. Compared with the sham-operated group, the SCF and c-kit mRNA levels in the BDL $24 \mathrm{~h}$ and BDL $48 \mathrm{~h}$ groups, respectively, were $1.0000 \pm 0.00000 \mathrm{vs} .0 .4400 \pm 0.09539 \mathrm{vs}$. $0.2000 \pm 0.08544$ and $1.0000 \pm 0.0000$ vs. $0.5967 \pm 0.05132$ vs. $0.2833 \pm 0.08622$ ( $F$-values respectively were 92.488 and 115.401 , all $P<0.05$ ).

The RT-PCR results supported the findings of immunohistofluorescence and western blot. Reduced expression of SCF and c-kit mRNA might affect the gallbladder ICCs function in acute cholecystitis (Fig. 6).

\section{Discussion}

Acute cholecystitis is an acute inflammatory disease of the gallbladder, influenced by many factors such as gallstones, motility disorders, and direct chemical injury [2]. It is a common diagnosis in both internal and surgery departments, and surgery is usually indicated for treatment. Furthermore, the heterogeneity of clinical presentation makes diagnosis and management difficutl [1]. Moreover, most acute cholecystitis is accompanied by gallbladder motility disorder $[2,3]$.

Gallbladder motility is regulated by various mechanisms, such as the activity of the gallbladder smooth muscle and nervous circuit, which includes gallbladder ICCs. ICCs 


\section{Cellular Physiology Cell Physiol Biochem 2016;38:1775-1784 \\ \begin{tabular}{c|c|c|} 
DOI: 10.1159/000443116 & $\begin{array}{l}\text { O 2016 The Author(s). Published by S. Karger AG, Basel } \\
\text { wwww.karger.com/cpb }\end{array}$
\end{tabular} \\ Huang et al.: Gallbladder Interstitial Cells of Cajal Injured in Acute Cholecystitis}

were first described in the gastrointestinal tract by Santiago Ramo'n y Cajal in 1893 [16, 17]. More recently, studies have found out ICCs are also distributed in the gallbladder and extrahepaticbiliary duct of both guinea-pigs and human beings [18-20]. ICCs in the biliary system may function as pacemakers for smooth muscle to generate and spread the spontaneous contractions of the gallbladder, promoting gastrointestinal electrical activity and mediating and regulating the neurotransmitters in the gastrointestinal tract [4-9]. Further, gallbladder ICCs have been linked to various biliary system diseases such as acute cholecystitis and cholelithiasis [10]. ICC damage and/or loss has been observed in almost every gastrointestinal motility disorder, and abnormalities in motor activity would impair regional transit and symptoms [21].

ICCs express a specific marker, c-kit [22]. In this study, the gallbladder ICCs were positive for c-kit in immunofluorescent staining and were distributed throughout the muscular layer of the gallbladder. Further, most were found within the muscularis propria and parallel to smooth muscle cells. They typically appeared singly or in small clusters of two to three cells, and were connected with each other to form a network, consistent with previous reports [10]. Recent studies have confirmed that ICCs in biliary system play an important role in initiating pacemaker activity to adjust gallbladder movement, and their dysfunction is closely linked to a variety of gallbladder motility disorders [22-24].

Pervious studies have also shown that ICCs would undergo apoptosis over time and that regeneration was required for maintenance of normal ICC networks in healthy tissue [25]. Various factors have been implicated in ICC loss, such as regional obstruction and subsequent proximal dilation and injury to the nervous system and immune system [21]. Studies on animal models have found that ICC viability and function are compromised in bowel obstruction and that ICCs nearly disappear when Kit receptors are blocked [21, 26, 27]. During acute cholecystitis, biliary tract obstruction would injure ICCs in the gallbladder and block Kit receptors, leading to decreased in the density of gallbladder ICCs, thereby impairing the regeneration and maintenance of ICC networks. Reduced density of gallbladder ICCs might have a substantial effect on acute cholecystitis with gallbladder motility disorder. However, further studies are needed to determine the mechanism of gallbladder ICC loss during acute cholecystitis.

ICC not only act to initiate pacemaker activity for modulating gallbladder motility, but also mediate neurotransmission from enteric motor neurons [28]. Recent studies have demonstrated that LPA1/3 receptor, opioid receptor, the tyrosine kinase receptor c-kit and its ligand-SCF play an important part in the normal development, maturation, and phenotype maintenance of ICCs [29-32]. Studies have also shown that the kit receptor modulates the generation and rhythmicity of the electrical activity that regulates the excitability of gallbladder smooth muscle [23]. However, during acute cholecystitis, biliary tract obstruction would injure ICCs in the gallbladder and block the tyrosine kinase receptor c-kit and its ligand-SCF, the expression both of c-kit and SCF mRNA and protein were significantly decreased, the SCF/c-kit pathway was repressed, and ICC numbers were reduced [33].The mechanism through which the SCF/c-kit pathway is repressed remains unknown. In this study, we observed that SCF/c-kit protein and mRNA were expressed in the gallbladder of guinea pigs with acute cholecystitis. This suggests that acute cholecystitis affecting the development of ICCs. Repression of the SCF/c-kit pathway might affect gallbladder ICCs function in acute cholecystitis.

In summary, our findings indicate that acute cholecystitis can decrease ICCs through repression of SCF and c-kit expression and that ICCs loss play a role in acute cholecystitis, and it may have relationships with gallbladder motility disorder.

\section{Acknowledgements}

This study was supported by National Natural Science Foundation of China (NSFC) (NO. 81170351). 


\title{
Cellular Physiology Cell Physiol Biochem 2016;38:1775-1784 \begin{tabular}{l|l} 
and Biochemistry 10.1159/000443116 & $\begin{array}{l}\text { Do } 2016 \text { The Author(s). Published by S. Karger AG, Basel } \\
\text { www.karger.com/cpb }\end{array}$
\end{tabular} \\ Huang et al.: Gallbladder Interstitial Cells of Cajal Injured in Acute Cholecystitis
}

\section{Disclosure Statement}

\author{
No conflict of interest.
}

\section{References}

1 Ambe PC, Papadakis M, Zirngibl H: A proposal for a preoperative clinical scoring system for acute cholecystitis. J Surg Res 2016;200:473-479.

2 Kimura Y, Takada T, Kawarada Y, Nimura Y, Hirata K, Sekimoto M, Yoshida M, Mayumi T, Wada K, Miura F, Yasuda H, Yamashita Y, Nagino M, Hirota M,Tanaka A, Tsuyuguchi T, Strasberg SM, Gadacz TR: Definitions, pathophysiology, and epidemiology of acute cholangitis and cholecystitis: Tokyo Guidelines. J Hepatobiliary Pancreat Surg 2007;14:15-26.

3 Parkman HP, Bogar LJ, Bartula LL, Pagano AP, Thomas RM, Myers SI: Effect of experimental acalculous cholecystitis on gallbladder smooth muscle contractility. Dig Dis Sci 1999,44:2235-2243.

4 Al-Shboul OA: The importance of interstitial cells of cajal in the gastrointestinal tract. Saudi J Gastroenterol 2013;19:3-15.

5 Sanders KM, Ward SM, Koh SD: Interstitial cells: regulators of smooth muscle function. Physiol Rev 2014;94:859-907.

6 Abramovic M, Radenkovic G, Velickov A: Appearance of interstitial cells of Cajal in the human midgut. Cell Tissue Res 2014;356:9-14.

7 Lies B, Gil V, Groneberg D, Groneberg D, Seidler B, Saur D, Wischmeyer E, Jiménez M, Friebe A: Interstitial cells of Cajal mediate nitrergic inhibitory neurotransmission in the murine gastrointestinal tract. Am J Physiol Gastrointest Liver Physiol 2014;307:G98-106.

8 Huizinga JD, Chen JH, Mikkelsen HB: Interstitial cells of Cajal, from structure to function. Front Neurosci 2013;7:43.

9 Huizinga JD, Chen JH: Interstitial cells of Cajal: update on basic and clinical science. Curr Gastroenterol Rep 2014;16:363.

10 Pasternak A, Gil K, Matyja A, Gajda M, Sztefko K, Walocha JA, Kulig J, Thor P: Loss of gallbladder interstitial Cajal-like cells in patients with cholelithiasis. Neurogastroenterol Motil 2013;25:e17-24.

11 Yip D, Zalcberg J, Ackland S, Barbour AP, Desai J, Fox S, Kotasek D, McArthur G, Smithers BM: Controversies in the management of gastrointestinal stromal tumors. Asia Pac J Clin Oncol 2014;10:216-227.

12 Zhang L, Pan C, Yang B, Xiao Y, Yu B: Enhanced expression of cystathionine $\beta$-synthase and cystathionine $\gamma$-lyase during acute cholecystitis-induced gallbladder inflammation. PLoS One 2013;8:e82711.

13 Tag CG, Weiskirchen S, Hittatiya K, Tacke F, Tolba RH Weiskirchen R: Induction of experimental obstructive cholestasis in mice. Lab Anim 2015;49:70-80.

14 Soylu S, Aydin C, Bagcivan I, Yildirim S, Koyuncu A, Topcu O, Arici S: Effects of NO/L-arginine pathway on gallbladder contractility in bile duct ligated guinea pigs. J Surg Res 2009;155:70-76.

15 Gomez-Pinilla PJ, Camello PJ, Pozo MJ: Effects of melatonin on gallbladder neuromuscular function in acute cholecystitis. J Pharmacol Exp Ther 2007;323:138-146.

16 Sanders KM, Ward SM: Interstitial cells of Cajal: a new perspective on smooth muscle function. J Physiol 2006;576:721-726.

17 Thuneberg L: One hundred years of interstitial cells of Cajal. Microsc Res Tech 1999;47:223-238.

18 Huang Y, Mei F, Yu B, Zhang HJ, Han J, Jiang ZY, Zhou DS: Distribution of the interstitial Cajal-like cells in the gallbladder and extrahepatic biliary duct of the guinea-pig. Acta Histochem 2009;111:157-165.

19 Hinescu ME, Ardeleanu C, Gherghiceanu M, Popescu LM: Interstitial Cajal-like cells in human gallbladder. J Mol Histol 2007;38:275-284.

20 Ahmadi O, Nicholson Mde L, Gould ML, Mitchell A, Stringer MD: Interstitial cells of Cajal are present in human extrahepatic bile ducts. J Gastroenterol Hepatol 2010;25:277-285.

21 Jan D. Huizinga, Natalia Zarate, Gianrico Farrugia: Physiology, injury and recovery of interstitial cells of Cajal: basic and clinical science. Gastroenterology 2009;137:1548-1556.

22 Yue Huang, Feng Mei, Bin Yu, Hong-jun Zhang, Juan Han, Zhong-yong Jiang, De-shan Zhou: Distribution of the interstitial Cajal-like cells in the gallbladder and extrahepatic biliary duct of the guinea-pig. Acta Histochem 2009;111:157-165. 


\section{Cellular Physiology Cell Physiol Biochem 2016;38:1775-1784 \begin{tabular}{ll|l} 
DOI: 10.1159/000443116 & $\begin{array}{l}\text { O 2016 The Author(s). Published by S. Karger AG, Basel } \\
\text { www.karger.com/cpb }\end{array}$ \\
\cline { 2 - 3 }
\end{tabular} \\ Huang et al.: Gallbladder Interstitial Cells of Cajal Injured in Acute Cholecystitis}

23 Lavoie B, Balemba OB, Nelson MT, Ward SM, Mawe GM: Morphological and physiological evidence for interstitial cell of Cajal-like cells in the guinea pig gallbladder. J Physiol 2007;579:487-501.

24 Fan Y, Wu S, Fu B, Weng C, Wang X: The role of interstitial Cajal-like cells in the formation of cholesterol stones in guinea pig gallbladder. Hepatol Int 2015;9:612-620.

25 Simon J. Gibbons, Roberto De Giorgio, Maria Simonetta Faussone Pellegrini, Megan M. Garrity-Park, Steven M. Miller, Philip F. Schmalz, Tonia M. Young-Fadok, David W. Larson, Eric J. Dozois, Michael Camilleri, Vincenzo Stanghellini, Joseph H. Szurszewski, Gianrico Farrugia: Apoptotic Cell Death of Human Interstitial Cells of Cajal. Neurogastroenterol Motil 2009;21:85-93.

26 Chang IY, Glasgow NJ, Takayama I, Horiguchi K, Sanders KM, Ward SM: Loss of interstitial cells of Cajal and development of electrical dysfunction in murine small bowel obstruction. J Physiol 2001;536:555-568.

27 Torihashi S, Nishi K, Tokutomi Y, Nishi T, Ward S, Sanders KM: Blockade of kit signaling induces transdifferentiation of interstitial cells of cajal to a smooth muscle phenotype. Gastroenterology 1999;117:140-148.

28 Sanders KM, Ordög T, Koh SD, Torihashi S, Ward SM: Development and plasticity of interstitial cells of Cajal. Neurogastroenterol Motil 1999;11:311-338.

29 Kim BJ, Nam JH, Kim KH, Joo M, Ha TS, Weon KY, Choi S, Jun JY, Park EJ, Wie J, So I, Nah SY: Characteristics of gintonin-mediated membrane depolarization of pacemaker activity in cultured interstitial cells of Cajal. Cell Physiol Biochem 2014;34:873-890.

30 Gim H, Nam JH, Lee S, Shim JH, Kim HJ, Ha KT, Kim BJ: Quercetin Inhibits Pacemaker Potentials via Nitric Oxide/cGMP-Dependent Activation and TRPM7/ANO1 Channels in Cultured Interstitial Cells of Cajal from Mouse Small Intestine. Cell Physiol Biochem 2015;35:2422-2436.

31 Fan Y, Wu S, Fu B, Yan X, Wang X, Zhang W: Decreased expression of stem cell factor mRNA and protein in the gallbladders of guinea pigs fed on high cholesterol diet. Int J Clin Exp Med 2015;8:6379-6383.

32 Rich A, Miller SM, Gibbons SJ, Malysz J, Szurszewski JH, Farrugia G: Local presentation of Steel factor increases expression of c-kit immunoreactive interstitial cells of Cajal in culture. Am J Physiol Gastrointest Liver Physiol 2003;284:G313-320.

33 Hu WM, Luo HS, Ding XW: Expression of C-kit messenger ribonucleic acid and C-kit protein in the gallbladders in guinea pigs of high cholesterol diet. Dig Dis Sci 2009;54:1651-1655. 